\title{
Tempat sampah otomatis berbasis Internet of Things dengan penyulangan hybrid PV-grid
}

\author{
Aldi Irvan Darmansyah ${ }^{1 *}$, Arif Sumardiono², Erna Alimudin ${ }^{3}$, Maya Rahayu ${ }^{4}$ \\ 1,2,3 Jurusan Teknik Elektro, Politeknik Negeri Cilacap \\ Jl. Dr. Soetomo No. 1, Sidakaya. Cilacap, Jawa Tengah, Indonesia \\ ${ }^{4}$ Jurusan Teknik Elektro, Politeknik Negeri Bandung \\ Jl. Gegerkalong Hilir, Ds. Ciwaruga, Kabupaten Bandung Barat, Jawa Barat, Indonesia \\ 1*aldi.irvan05@gmail.com, ${ }^{2}$ arifsumardiono@pnc.ac.id, ${ }^{3}$ ernaalimudin@pnc.ac.id, ${ }^{4}$ mayarahayu@polban.ac.id
}

\begin{abstract}
ABSTRAK
Tempat sampah otomatis adalah sebuah alat yang mempermudah seseorang dalam membuang sampah. Tutup tempat sampah yang dapat membuka dan menutup secara otomatis memiliki tujuan agar menghindari terinfeksinya bakteri pada tutup. Penumpukan sampah dapat menyebabkan bau tidak sedap hingga polusi udara. Tempat sampah otomatis di luar ruangan sangat sulit terakses listrik sehingga diperlukan penyuplai listrik portable. Penelitian ini bertujuan untuk pembuatan tempat sampah otomatis berbasis Internet of Things (IoT) menggunakan sistem hybrid PV-grid. Sistem ini menambahkan fungsi dari tempat sampah otomatis yaitu untuk memberikan notifikasi terhadap petugas kebersihan jika tempat sampah telah penuh. Sistem suplai listrik menggunakan hybrid dua penyulangan yaitu photovoltaic (PV) dan listrik konvensional (grid). Perancangan sistem kontrol tempat sampah otomatis menggunakan sensor ultrasonik, modul mikrokontroler Arduino Uno, dan modul GSM. Hasil pengujian menunjukkan pengisian baterai hingga penuh membutuhkan waktu 3,39 jam dan mengirimkan notifikasi jika sensor ultrasonik mendeteksi sampah dengan jarak $20 \mathrm{~cm}$ selama 5 detik. Sistem pemberitahuan notifikasi juga berhasil dikirimkan menggunakan media SMS.
\end{abstract}

Kata kunci: Arduino Uno, hybrid, photovoltaic, tempat sampah otomatis

\section{ABSTRACT}

Automatic trash bin is a tool that makes it easier for someone to dispose of garbage. The lid of the trash bin that can open and close automatically has the aim of avoiding bacterial infection on the lid. The accumulation of garbage can cause unpleasant odors to air pollution. Outdoor automatic trash binss are very difficult to access, so a portable power supply is needed. This study aims to create an Internet of Things (IoT) based automatic trash can using a hybrid PV-grid system. This system adds the function of the automatic trash can, which is to notify the cleaners when the trash bin is full. The electricity supply system uses a hybrid of two feeders, namely photovoltaic $(P V)$ and conventional electricity (grid). The design of the automatic trash can control system uses ultrasonic sensors, Arduino Uno microcontroller modules, and GSM modules. The test results show that fully charging the battery takes 3.39 hours and sends a notification if the ultrasonic sensor detects garbage with a distance of $20 \mathrm{~cm}$ for 5 seconds. The notification notification system was also successfully sent using SMS media.

Keywords: Arduino Uno, hybrid, photovoltaic, automatic trash bin

\section{PENDAHULUAN}

Permasalahan sampah merupakan salah satu masalah yang serius dalam isu lingkungan. Jika pengelolaan sampah tidak ditangani dengan baik, maka akan dapat menyebabkan timbulnya berbagai permasalahan seperti gangguan kesehatan. Selain itu, timbunan sampah juga dapat menjadi sumber virus dan bakteri [1]. Pengolahan sampah yang buruk dapat menyebabkan masalah lingkungan yang merugikan. Tempat sampah yang sudah disediakan oleh instansi kebersihan masih menggunakan cara sederhana yaitu dengan membuka dan menutup tutup tempat sampah secara manual. Hal ini akan menyebabkan tangan akan sangat rawan terkena bakteri dari tempat sampah tersebut [2]. Masalah yang membuat penimbunan sampah dan terinfeksinya tutup tempat sampah oleh bakteri dan virus. Maka dari itu, diperlukan tempat sampah yang dapat memberikan notifikasi kepada petugas 
kebersihan apabila tempat sampah telah penuh untuk mencegah penimbunan. Kemudian, tempat sampah akan lebih aik jika dapat membuka dan menutup secara otomatis agar tangan tidak terinfeksi oleh bakteri dan virus pada tutup.

Tempat sampah otomatis dapat dikendalikan melalui mikrokontroler dengan menggunakan sumber energi listrik yang tepat. Dari sekian banyak sumber energi terbarukan, penggunaan energi melalui solar cell atau photovoltaic (PV) merupakan alternatif yang paling potensial untuk diterapkan di wilayah Indonesia. Energi surya adalah salah satu sumber energi bersih paling menjanjikan, energi terbarukan, dan potensi paling tinggi dibanding sumber energi lainnya untuk menyelesaikan masalah energi dunia. Indonesia merupakan negara tropis dan berlokasi di garis ekuator dengan potensi energi surya yang berlimpah [3]. Salah satu solusi yang tepat untuk mengurangi pengunaan bahan bakar minyak/fosil yaitu dengan menggunakan PV.

Beberapa penelitian telah dilakukan untuk membuat tempat sampah otomatis. Penelitian [4] telah membuat trainer tempat sampah otomatis dengan menggunakan sensor inframerah dengan pemberi notifikasi berupa tampilan LCD. Hal serupa juga dilakukan oleh [5] dengan merancang sistem tempat sampah otomatis menggunakan sensor PIR sebagai sensor jarak. Kemudian penelitian [6] merancang tempat sampah otormatis menggunakan buzzer sebagai notifikasi tempat sampah penuh. Notifikasi SMS untuk memberitahukan kondisi alat dengan menggunakan modul GSM telah dilakukan penelitian oleh [7].

Kemudian berbagai penelitian juga telah mengulas tentang berbagai sumber listrik yang digunakan pada yang dibahas pada jurnal ini. Pada peneliatian [8] telah mengulas tentang penyulangan lsitrik menggunakan PV 50 Wattpeak dengan penyerapan energi surya yang baik. Penelitian [9] telah merancang sistem pengisian daya baterai menggunakan tiga penyulangan. Selanjutnya, penelitian [10] telah melakukan pengujian Automatic Transfer System (ATS) PV-grid yang digunakan untuk mengalihkan penyulangan jika salah satu penyulangan bermasalah.

Penelitian ini bertujuan untuk merancang tempat sampah otomatis yang dapat memberikan notifikasi berupa SMS agar tidak terjadi penumpukan sampah. Sistem ini juga didukung dengan dua penyulangan yaitu PV-grid sehingga lebih portable. Kedua penyulangan lsitrik dikontrol menggunakan ATS agar tempat sampah selalu mendapat suplai tegangan saat PV melakukan pengisian baterai. Sistem tempat sampah otomatis dirancang menggunakan sensor ultrasonik HCSR04. Data kemudian diproses melalui Arduino Uno sehingga dapat menggerakkan motor servo. Jika tempat sampah penuh maka sensor HC-SR04 kedua akan mendeteksi. Kemudian modul GSM akan mengirimkan SMS kepada petugas kebersihan.

\section{METODE PENELITIAN}

\subsection{Perangkat Keras}

Gambar 1 menjelaskan tentang dua sistem yang terdiri dari sistem hybrid dan sistem kontrol dari tempat sampah otomatis. Pertama, sistem suplai daya adalah sistem yang memberikan sumber tegangan kepada sistem kontrol agar dapat bekerja. Sistem suplai yang digunakan adalah sistem penyulangan hybrid sehingga dapat dikatakan sistem ini memiliki dua sumber suplai yang berbeda. Penyulangan pertama dari PV dan yang kedua adalah grid (konvensional/PLN). Pada sistem suplai hybrid ini memiliki sistem ATS yang memungkinkan untuk mengubah sumber suplai tenaga listrik secara otomatis. Seperti contohnya, apabila PV tidak mendapat sumber yang cukup dan tidak memiliki daya maka relay hybrid akan switch ke grid. Begitupun sebaliknya, apabila grid tidak memiliki sumber tegangan makan akan di switch ke PV. Namun, di luar sistem tersebut alat ini juga dapat terfokus ke satu sumber suplai tenaga listrik.

Kedua, sistem kontrol yang mengendalikan kerja dari tempat sampah dan lampu penerangan. Mikrokontroler yang digunakan adalah Arduino Uno untuk mengontrol kinerja input dan output secara terprogram. Cara kerja dari sistem kedua ini adalah apabila sonsor ultrasonik 1 mendeteksi benda, maka motor servo akan membuka tempat sampah selama 3 detik kemudian motor servo akan kembali menutup. Jika sensor ultrasonik 1 sudah tidak mendeteksi benda lagi, maka LCD akan menampilkan tulisan "Terima kasih". Kemudian apabila sensor ultrasonik 2 mendeteksi benda, maka menandakan bahwa tempat sampah sudah penuh. Pada kondisi ini, modul GSM akan mengirimkan SMS ke ponsel petugas kebersihan berupa alamat di mana tempat sampah tersebut diletakkan. Setelah itu LCD akan menampilkan tulisan "Tempat sampah sudah penuh". Pada kondisi tempat sampah penuh maka motor 
motor servo tidak akan bekerja hingga tempat sampah tersebut kosong. Sistem penerangan dikontrol dengan sensor LDR yang akan bekerja tergantung intensitas cahaya yang diterima. Dengan begitu modul relay akan mengontrol lampu DC.
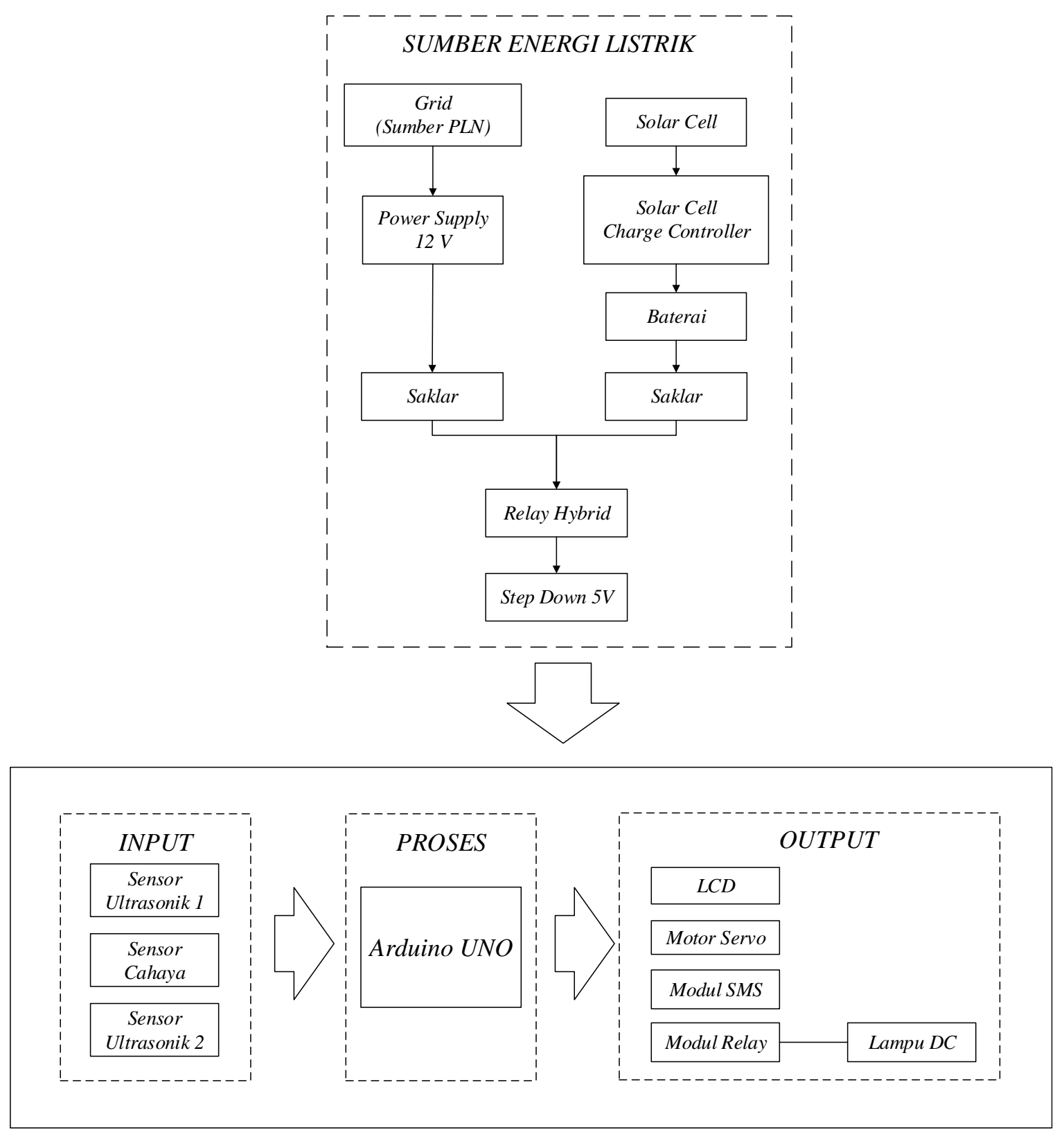

Gambar 1. Diagram blok sistem

Gambar 2 menunjukkan porses konversi energi dari PV sampai mengeluarkan tegangan $5 \mathrm{~V}$. Jika PV mendapat cahaya matahari maka photon akan dikonversikan dalam energi listrik DC dengan tegangan maksimal 18,2 V. Tegangan tersebut akan distabilkan solar charger controller (SCC) untuk mengatur keluar masuknya tegangan dari PV menuju ke baterai. Jika baterai masih memiliki daya maka tegangan akan disalurkan ke relay hybrid dan diturunkan teganganya menjadi 5 VDC. Jika tegangan grid tersedia maka tegangan akan disearahkan dan diturunkan menajdi 12 VDC yang akan mengaktifkan relay hybrid, dan kemudian diturunkan tegangannya menggunakan stepdown DC agar dapat digunakan untuk menyupali sistem. Sumber listrik PV merupakan sumber utama untuk menyuplai sistem. Jika sumber PV mati, maka sumber grid yang akan menyuplai sistem, dan jika kedua sumber mati maka sistem tidak akan bekerja karena tidak mendapat tegangan. 


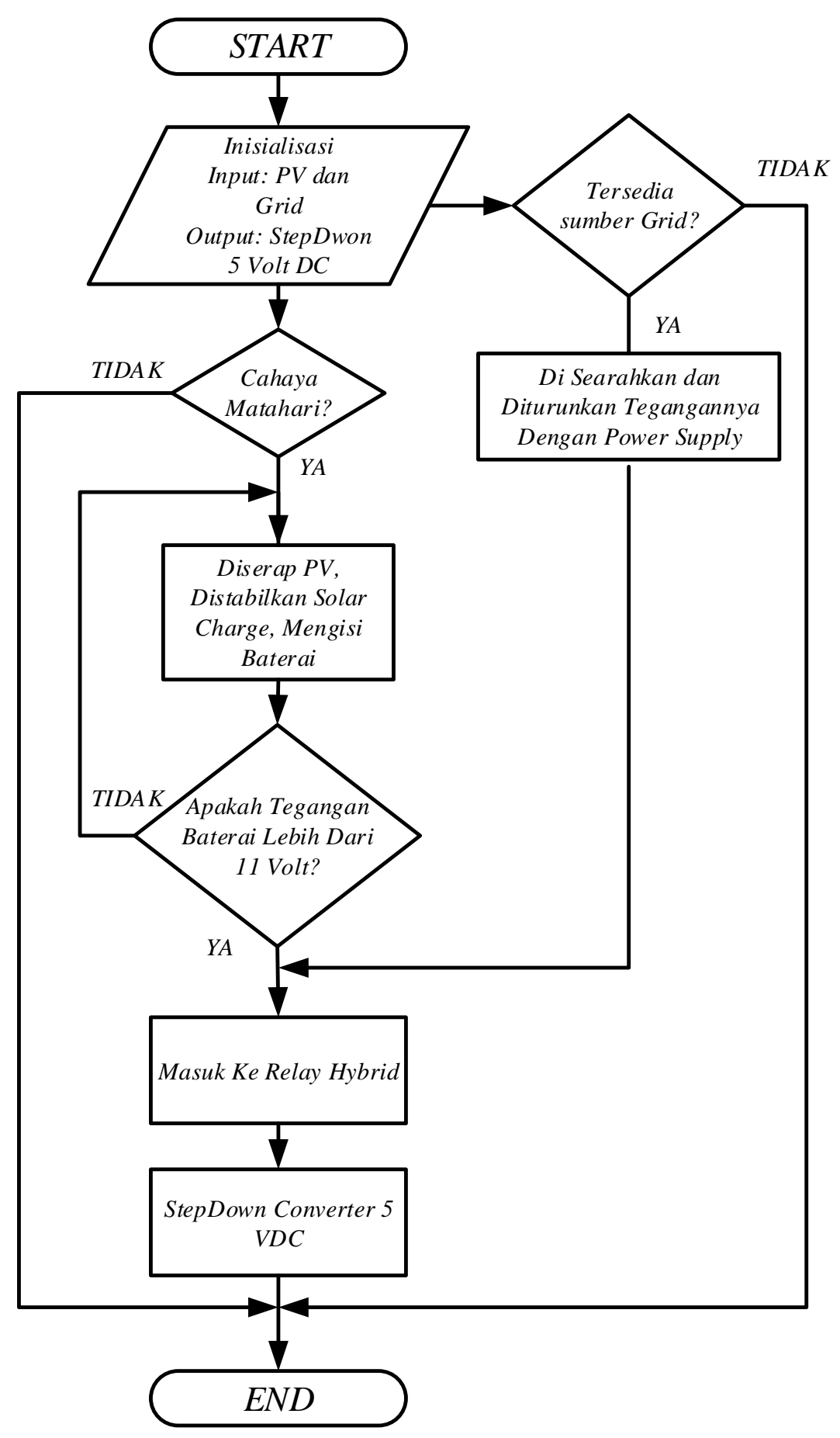

Gambar 2. Flowchart sistem hybrid PV-grid

Gambar 3 menjelaskan bahwa jika sensor ultrasonik 1 mendeteksi benda dengan jarak $30 \mathrm{~cm}$, maka akan menggerakkan motor servo untuk membuka tempat sampah selama 3 detik dan akan menutup jika sensor ultrasonik 1 tidak mendeteksi benda setelah itu akan menampilkan tulisan "Terima kasih" pada LCD selama 3 detik. Jika sensor ultasonik 2 mendeteksi benda maka modul GSM akan menigirimkan SMS ke petugas kebersihan berupa alamat tempat sampah itu diletakkan dan saat itu juga motor servo tidak akan bekerja hingga sampah dikosongkan, dengan notifikasi yang diberikan pada LCD dengan tulisan "Tempat Sampah Sudah Penuh". Kemudian sensor cahaya digunakan untuk menyalakan lampu penerangan secara otomatis dengan memanfaatkan intensitas cahaya. 


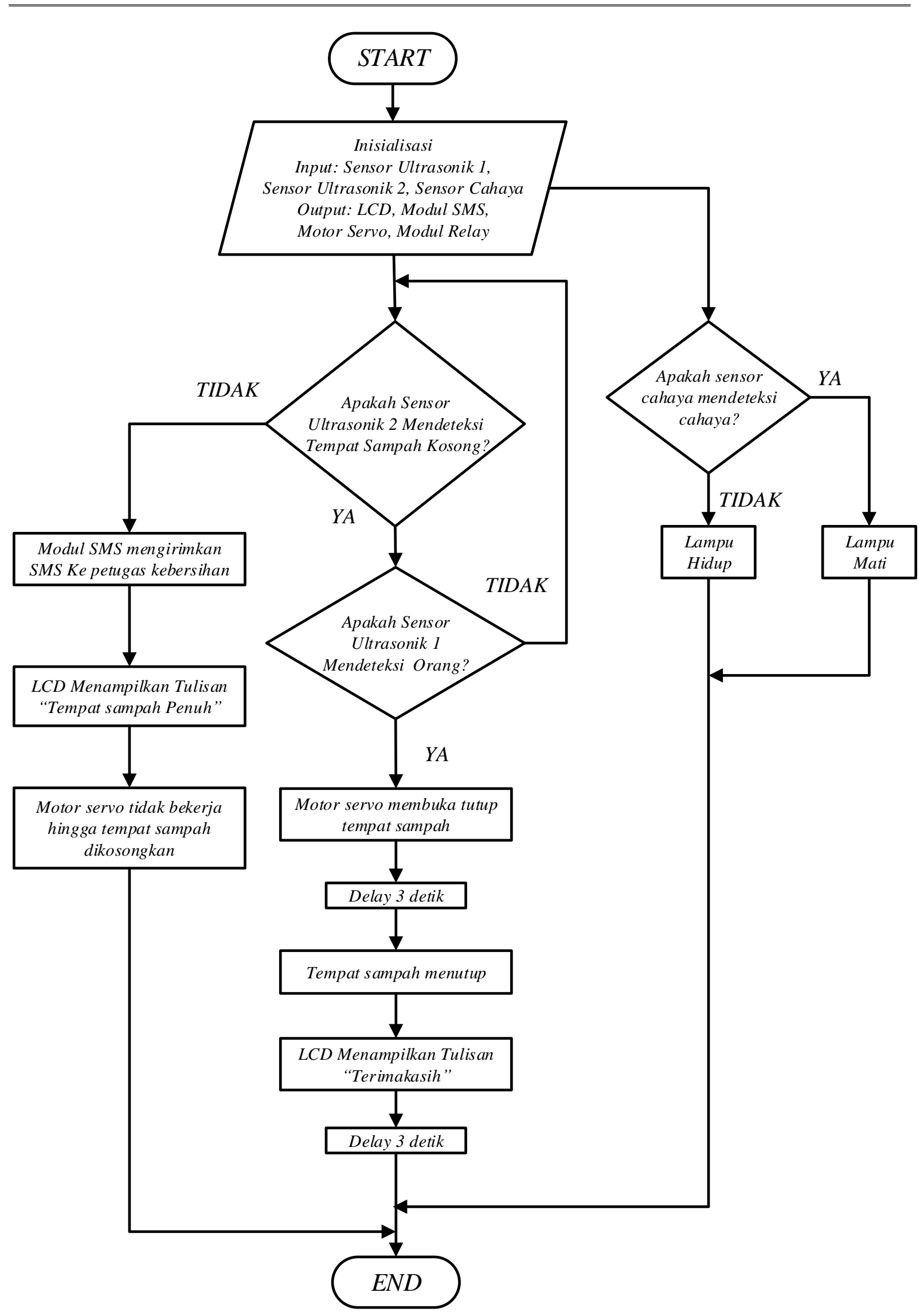

Gambar 3. Flowchart sistem kerja tempat sampah otomatis 


\subsection{Perancangan Rangkaian Kontroler}

Pada perancangan rangkaian kontrol, proses yang dilakukan adalah pembuatan layout schematic rangkaian hingga ke layout PCB. Pada mainboard berisi pin header-header yang menghubungkan sensor dan aktuator ke pin yang terdapat di Arduino Uno mulai sensor ultrasonik, sensor LDR, motor servo, modul GSM, dan LCD. Konfigurasi mainboard direpresentasikan pada Gambar 4.

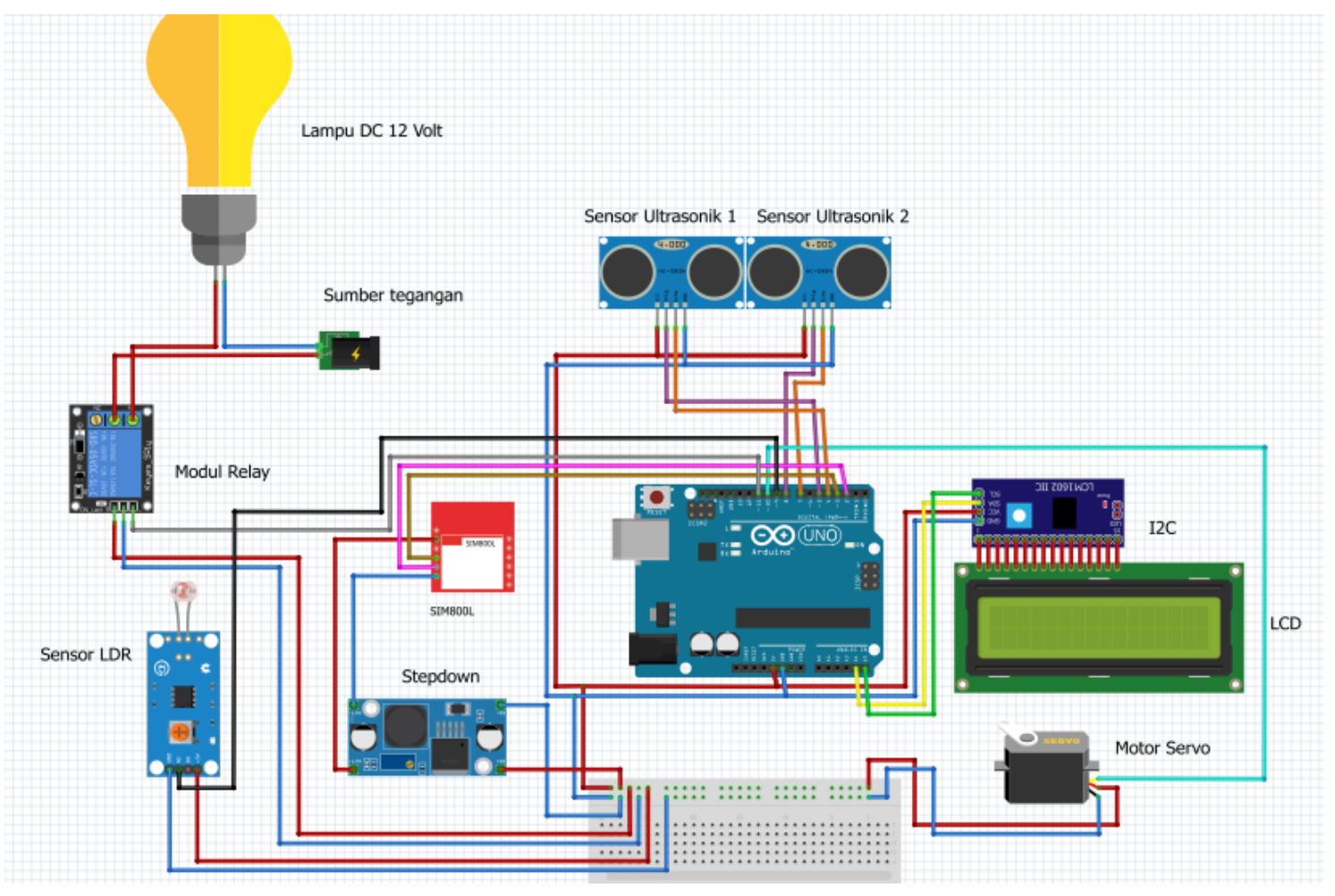

Gambar 4. Rangkaian mainboad keseluruhan

Pada Gambar 4 menujukan wiring dari setiap komponen. Setiap kabel merah (5V) disambungkan ke VCC Arduino Uno dan kabel biru (GND) disambungkan ke GND Arduino Uno. Sumber tegangan diambil dari stepdown 5V. Keterangan lebih jelasnya dapat dilihat pada Tabel 1.

Tabel 1. Wiring komponen dengan Arduino Uno

\begin{tabular}{|c|l|l|}
\hline \multirow{2}{*}{ Komponen } & \multicolumn{2}{|c|}{ Pin } \\
\cline { 2 - 3 } & \multicolumn{1}{|c|}{ Komponen } & Arduino \\
\hline Motor servo - Arduino UNO & Kabel biru muda (sinyal) & Pin 9 \\
\hline \multirow{2}{*}{ Sensor ultrasonik 1 - Arduino UNO } & Kabel jingga (echo) & Pin 4 \\
\cline { 2 - 3 } & Kabel ungu (Trigger) & Pin 5 \\
\hline \multirow{2}{*}{ Sensor ultrasonik 2 - Arduino UNO } & Kabel jingga (echo) & Pin 6 \\
\cline { 2 - 3 } & Kabel ungu (Trigger) & Pin 7 \\
\hline \multirow{2}{*}{ LCD I2C - Arduino UNO } & Kabel hijau (SDA) & Pin A2 \\
\cline { 2 - 3 } & Kebel kuning (SCL) & Pin A3 \\
\hline \multirow{2}{*}{ Modul GSM - Arduino UNO } & Kabel merah muda (TX) & Pin 2 \\
\cline { 2 - 3 } & Kabel coklat (RX) & Pin 3 \\
\hline Modul LDR - Arduino UNO & Kabel hitam (sinyal) & Pin 10 \\
\hline Modul relay - Arduino UNO & Kabel abu-abu (sinyal) & Pin 12 \\
\hline
\end{tabular}

\subsection{Perancangan Mekanik Hardware}

Perancangan alat terdiri dari beberapa body luar tempat sampah, bagian dalam tempat sampah, PV, box panel, dan tiang lampu penerangan. Adapun desain dari setiap bagian dapat dilihat pada Gambar 5. 


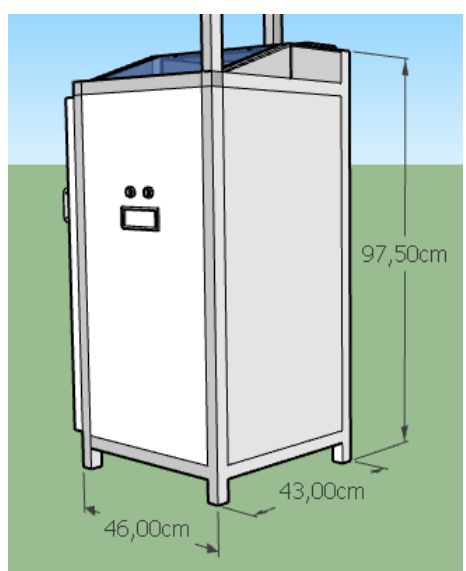

(a)

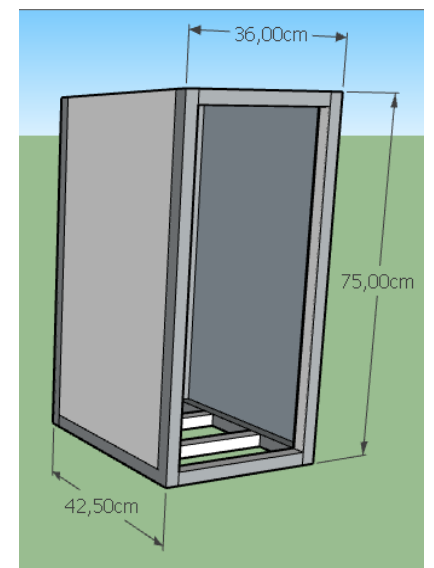

(b)

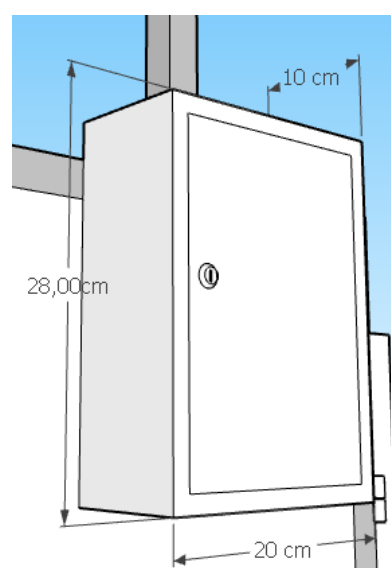

(c)

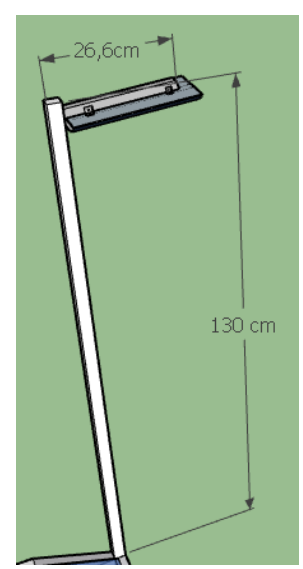

(d)

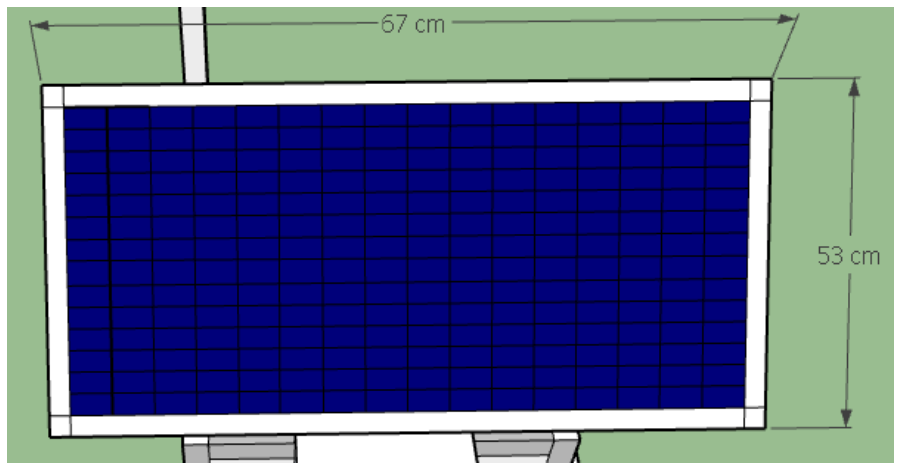

(e)

Gambar 5. Desain bagian-bagian hardware: (a) bagian luar, (b) bagian dalam, (c) panel box, (d) tiang lampu, (e) PV

Bagian-bagian dari desain memiliki dimensi yang berbeda-beda. Ukuran dimensinya dapat dilihat pada Tabel 2.

Tabel 2. Dimensi bagian bagian hardware

\begin{tabular}{|l|c|c|c|}
\hline \multirow{2}{*}{ Bagian-bagian } & \multicolumn{3}{|c|}{ Dimensi } \\
\cline { 2 - 4 } & Panjang $(\mathbf{c m})$ & Lebar $(\mathbf{c m})$ & Tinggi $(\mathbf{c m})$ \\
\hline Bagian luar & 46 & 43 & 97,5 \\
\hline Bagian dalam & 42,5 & 36 & 75 \\
\hline Panel box & 20 & 10 & 18 \\
\hline Tiang lampu & 3 & 26,6 & 130 \\
\hline Photovoltaic & 5 & 53 & 67 \\
\hline
\end{tabular}

Perancangan kerangka hardware menggunakan pipa hollow dengan dimensi $3 \mathrm{~cm}$ x $3 \mathrm{~cm}$ dengan ketebalan $2 \mathrm{~mm}$. Pipa hollow yang digunakan adalah jenis galvalum. Bahan galvalum selain bisa dilas dan kuat juga tahan karat sehingga cocok untuk diluar ruangan. Tutup hardware menggunakan akrilik bening dengan ketebalan $3 \mathrm{~mm}$.

\section{HASIL DAN PEMBAHASAN}

Bagian ini berisi tentang hasil pengujian PV, sistem hybrid, sistem kendali Arduino Uno, dan sistem IoT menggunakan modul GSM yang telah dirancang. Berikut adalah hardware yang telah dirancang ditunjukan pada Gambar 6. 

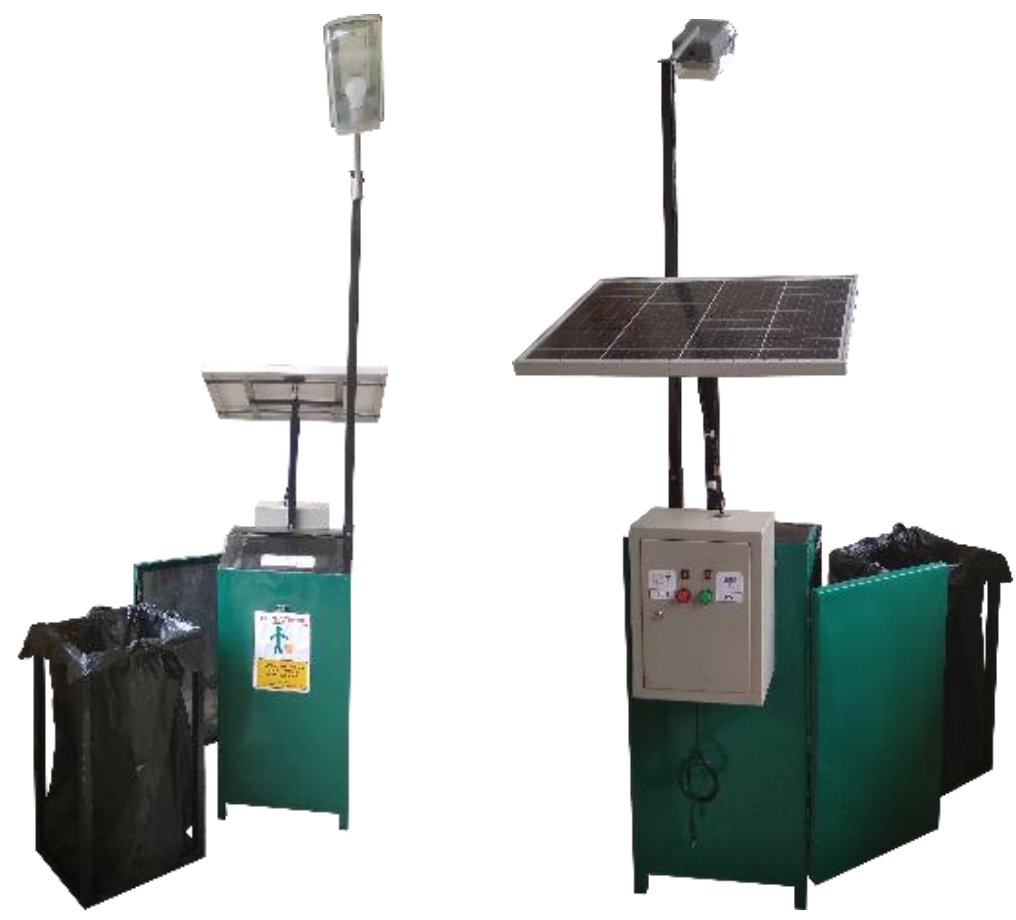

Gambar 6. Implementasi hardware

\subsection{Pengukuran Tegangan, Arus, dan Daya pada PV}

Pengukuran dilakukan menggunakan PV dengan power peak $60 \mathrm{Wp}$ monocrystaline dengan beban baterai dengan kapasitas $12 \mathrm{~V}, 9$ AH. Pengukuran dilakukan pada pukul 08.00 WIB sampai pukul 16.00 WIB. Pengambilan data dilakukan saat kondisi cerah dan berawan. Pengukuran dilakukan melalui Wattmeter yang dipasangkan antara SCC dan baterai. Hasil data dari pengukuran tegangan, arus, dan daya yang dihasilkan oleh PV ditunjukkan pada Gambar 7.

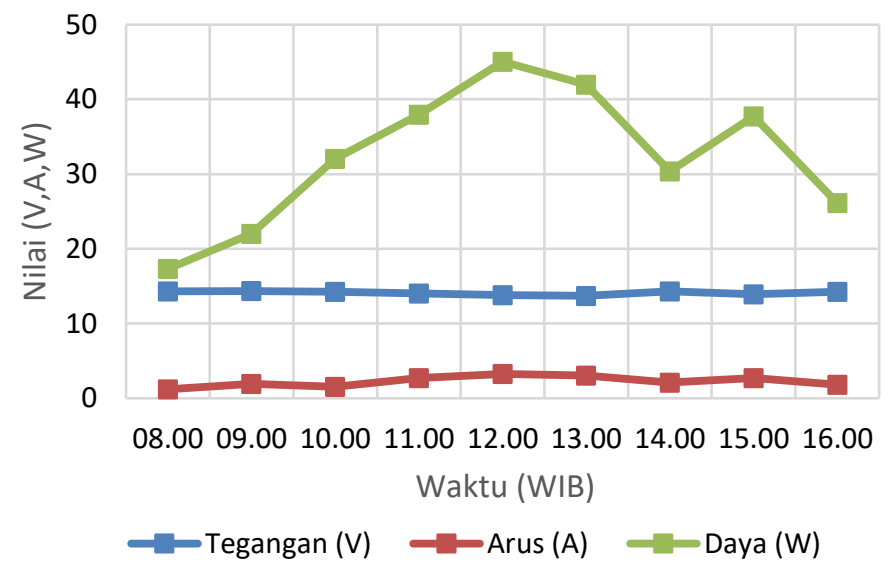

Gambar 7. Hasil pengukuran tegangan, arus, dan daya $P V$

Gambar 7 menunjukkan bahwa PV jenis monocrystaline jika dalam kondisi cuaca berawan akan menurunkan arus yang diserap. Karaktristik PV yang lain adalah apabila arus yang diserap tinggi maka tegangan yang dihasilkan akan menurun, sehingga daya yang dihasilkan akan stabil. Hal tersebut dikontrol oleh SCC. Berdasarkan hasil pengukuran, maka PV mengisi baterai dengan kapasitas $12 \mathrm{~V} 9$ Ah dengan perhitungan sebagai berikut:

1. Kapasitas baterai

$$
\begin{aligned}
& =\mathrm{V} \times \mathrm{I} \\
& =12 \times 9 \mathrm{Ah} \\
& =108 \mathrm{Wh} \\
& =31,79 \mathrm{~W}
\end{aligned}
$$

2. Daya rata-rata $\mathrm{PV}$ 
3. Waktu charging baterai $=\frac{\text { Kapasitas Baterai }}{\text { daya rata-rata } P V}$

$$
\begin{aligned}
& =\frac{108}{31,79} \\
& =3,39 \mathrm{Jam}
\end{aligned}
$$

\subsection{Pengujian Sistem Hybrid PV-Grid}

Sistem hybrid menggunakan relay sebagai saklar/switching otomatis untuk sumber listrik PV dan grid yang akan disalurkan ke beban. Namun sistem otomatis ini bisa difokuskan pada satu atau dua sumber tegangan yang mengatur pada saklar sumber suplainya. Jika ingin mematikan sistem dapat menonaktifkan kedua sumber, sehingga sistem akan mati dan tidak bekerja. Berikut adalah pengujian dari sistem switching PV-grid dapat dilhat pada Tabel 3.

Tabel 3. Hasil pengujian sistem hybrid PV-grid

\begin{tabular}{|c|c|c|c|}
\hline No. & Aksi & Reaksi & Keterangan \\
\hline 1 & $\begin{array}{c}\text { Saklar PV ON dan } \\
\text { saklar grid OFF }\end{array}$ & $\begin{array}{c}\text { Relay aktif dan kontak NO (Normally Open) } \\
\text { menjadi close, sehingga tegangan mengalir dari } \\
\text { baterai ke beban }\end{array}$ & $\begin{array}{c}\text { Beban disuplai oleh } \\
\text { baterai 12 V 9 Ah }\end{array}$ \\
\hline 2 & $\begin{array}{c}\text { Saklar grid ON dan } \\
\text { saklar PV OFF }\end{array}$ & $\begin{array}{c}\text { Relay non-aktif dan kontak NC (Normally Close) } \\
\text { menjadi open, sehingga tegangan mengalir dari } \\
\text { power supply ke beban }\end{array}$ & $\begin{array}{c}\text { Beban disuplai oleh } \\
\text { power supply }\end{array}$ \\
\hline
\end{tabular}

Berdasarkan Tabel 3, jika relay mendapat sumber tegangan, maka keadaan relay akan aktif dan beban akan tersuplai oleh baterai $12 \mathrm{~V} 9 \mathrm{Ah}$. Saat relay dalam kondisi tidak mendapat suplai tegangan sehingga relay dalam kondisi non-aktif, maka kontak relay berada pada posisi NC (Normally Close) sehingga beban akan disuplai oleh power supply.

\subsection{Pengujian Sistem Kendali pada Arduino Uno}

Pengujian ini dilakukan pada sistem yang terhubung ke mikrokontroler Arduino Uno. Pengujian dilakukan pada pergerakan motor servo, sistem IoT dengan modul GSM, dan lampu penerangan dengan sesnor LDR. Tabel 4 menunjukkan hasil pengujian sistem yang terhubung ke Arduino Uno.

\begin{tabular}{|c|c|c|c|}
\hline No. & Aksi & Kondisi & Reaksi \\
\hline 1 & $\begin{array}{l}\text { Sensor ultra sonik } 1 \text { tidak } \\
\text { mendeteksi benda }\end{array}$ & Tempat sampah kosong & Servo tidak bekerja \\
\hline 2 & $\begin{array}{l}\text { Sensor ultrasonik } 1 \text { mendeteksi } \\
\text { benda } 30 \mathrm{~cm}\end{array}$ & Tempat sampah belum penuh & $\begin{array}{l}\text { Servo bekerja, tempat } \\
\text { sampah membuka } 3 \text { detik }\end{array}$ \\
\hline 3 & $\begin{array}{l}\text { Sensor ultrasonik } 1 \text { mendeteksi } \\
\text { benda } 30 \mathrm{~cm}\end{array}$ & Tempat sampah penuh & Servo tidak bekerja \\
\hline 4 & $\begin{array}{l}\text { Sensor ultrasonik } 2 \text { tidak } \\
\text { mendeteksi sampah }\end{array}$ & Tempat sampah belum penuh & $\begin{array}{l}\text { Modul GSM tidak mengirim } \\
\text { SMS }\end{array}$ \\
\hline 5 & $\begin{array}{l}\text { Sensor ultrasonik } 2 \text { mendeteksi } \\
\text { sampah }\end{array}$ & Tempat sampah penuh & $\begin{array}{l}\text { Modul GSM mengirim SMS } \\
\text { dan servo tidak bekerja }\end{array}$ \\
\hline 6 & $\begin{array}{l}\text { Sensor cahaya mendeteteksi } \\
\text { sinar }\end{array}$ & - & Lampu mati \\
\hline 7 & $\begin{array}{l}\text { Sensor cahaya tidak } \\
\text { mendeteteksi sinar }\end{array}$ & - & Lampu hidup \\
\hline
\end{tabular}

Tabel 4. Hasil pengujian sistem Arduino Uno

Berdasarkan Tabel 4 tersebut, semua sistem bekerja dengan normal seperti pada perancangan awal. Servo bekerja jika sensor ultrasonik 1 mendeteksi objek. Kemudian modul GSM mengirimkan notifikasi SMS jika sensor ultrasonik telah mendeteksi sampah, dan lampu akan menyala jika sesnor LDR tidak mendapatkan cahaya.

Kemudian pengujian terakhir dilakukan pada sistem IoT. Pengujian sistem IoT ini menggunakan module GSM dengan tipe SIM 800L V2.0. Modul ini menggunakan provider XL-Axita dengan jaringan EDGE. Modul ini membutuhkan tagihan biaya jika ingin mengirimkan SMS. Jumlah biaya yang dibayarkan dapat dilihat melalui aplikasi smartphone Android yaitu myXL. Gambar 8 
menunjukkan hasil pengujian modul GSM mengirimkan SMS. Adapun hasil jarak dan waktu yang dapat mengirimkan SMS ke handphone dapat dilihat pada Tabel 5.

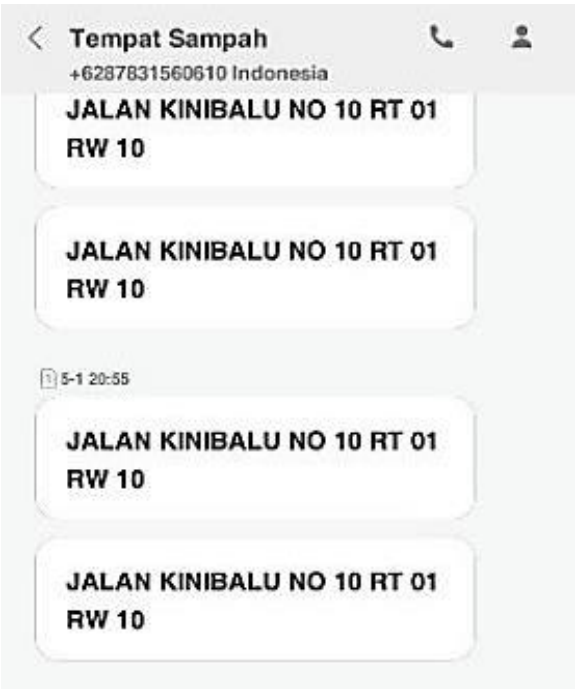

Gambar 8. Pengujian modul GSM mengirimkan SMS

Tabel 5. Hasil pengujian jarak dan waktu untuk mengirimkan SMS

\begin{tabular}{|c|c|c|l|}
\hline No. & Jarak (cm) & Waktu (detik) & \multicolumn{1}{|c|}{ Keterangan } \\
\hline 1 & 20 & 5 & Terkirim \\
\hline 2 & 25 & 5 & Tidak terkirim \\
\hline 3 & 5 & 2 & Tidak terkirim \\
\hline
\end{tabular}

Berdasarkan hasil pengujian, modul GSM dapat mengirimkan SMS jika jarak dan waktu sudah terpenuhi. Jika salah satu syarat tidak terpenuhi maka SMS tidak akan terkirim. Dengan demikian, sampah harus mencapai jarak $20 \mathrm{~cm}$ dalam waktu 5 detik agar dapat mengirimkan notifikasi SMS ke petugas kebersihan untuk diambil.

\section{KESIMPULAN}

Sistem tempat sampah otomatis berbasis IoT menggunakan hybrid PV-grid berhasil berhasil dirancang dengan memanfaatkan energi surya sebagai penyulang daya pada sistem. Berdasarkan pengujian sistem hybrid kedua penyulangan berhasil bekerja dengan baik. Jika baterai dalam kondisi habis maka suplai yang dari baterai akan berpindah ke grid sehingga sistem dapat berkerja selama 24 jam. Pengembangan selanjutnya dapat menambahkan sistem web server sehingga dapat mencakup data lebih bannyak. Selain itu, sistem dapat ditambahkan modul GPS sehingga dapat memantau posisi sistem melalui media website.

\section{UCAPAN TERIMAKASIH}

Terimkasih untuk Laboraotium Jurusan Teknik Elektronika, Politeknik Negeri Cilacap yang telah memberikan fasilitas unuk membantu dalam pengujian penelitian.

\section{REFERENSI}

[1] I. Purnama, S. Z. Harahap, and A. A. Ritonga, "Rancang Bangun Tempat Sampah Otomatis Pada Universitas Labuhanbatu," J. Inform., vol. 8, no. 2, pp. 81-84, 2020.

[2] A. Wuryanto, N. Hidayatun, M. Rosmiati, and Y. Maysaroh, "Perancangan Sistem Tempat Sampah Pintar Dengan Sensor HCRSF04 Berbasis Arduino UNO R3," Paradig. J. Komput. dan Inform. Univ. Bina Sarana Inform., vol. 21, no. 2, pp. 143-148, 2019.

[3] K. Kananda, "Studi Awal Potensi Energi Surya Wilayah Lampung: Studi Kasus Kampus Institut Teknologi Sumatera (ITERA) Menuju Smart Campus," J. Sci. Appl. Technol., vol. 1, no. 2, pp. 75-81, 2017.

[4] H. P. Putra and S. N. Wahid, "Pembuatan Trainer Tempat Sampah Otomatis Guna Menyiasati Masalah Sampah Di Lingkungan Masyarakat (Making Automatic Trash Trainer To Get Rid of Waste Problems in the Community Environment)," JEEE- $U$, vol. 3, no. 1, pp. 120-125, 2019. 
[5] C. R. Hidayat and F. D. Syahrani, "Perancangan Sistem Kontrol Arduino Pada Tempat Sampah Menggunakan Sensor Pir Dan Sensor Ultrasonik," J. Voice Informatics, vol. 6, 2017.

[6] S. Sukarjadi, A. Arifiyanto, D. T. Setiawan, and M. Hatta, "Perancangan Dan Pembuatan Smart Trash Bin Di Universitas Maarif Hasyim Latif,” Tek. Eng. Sains J., vol. 1, no. 2, pp. 101-110, 2017.

[7] D. Andesta and R. Ferdian, "Sistem Keamanan Sepeda Motor Berbasis Mikrokontroler dan Modul GSM," J. Inf. Technol. Comput. Eng., vol. 2, no. 02, pp. 51-63, 2018.

[8] R. Sinaga, "Pengaruh Parameter Lingkungan dan Penempatan Posisi Modul Terhadap Luaran Energi Plts Menggunakan Solar Cell 50 Wp, 12 Volt,” Stud. Teknol., vol. 1, no. 2, pp. 178-188, 2018.

[9] R. A. SADEWO, "Perancangan dan Implementasi Pengisian Baterai Lead Acid Menggunakan Solar Cell Dengan Menggunakan Metode Three Steps Charging," e-Proceeding Eng., vol. 4, no. 1, pp. 26-35, 2017.

[10] R. Majid, A. Eliza . Herdiansyah, "Alat Automatic Transfer Switch (Ats) Sebagai Sistem Kelistrikan Hybrid Sel Surya Pada Rumah Tangga,” Surya Energi, vol. 2, no. 2, pp. 172-178, 2018. 
